\title{
Glaciation of Chagvan Bay Area, Southwestern Alaska
}

\author{
STEPHEN C. PORTER ${ }^{1}$
}

\begin{abstract}
Morphologic and stratigraphic evidence near Chagvan Bay indicates that glaciers originating in the Ahklun Mountains spread over the coastal lowlands at least four times as broad piedmont lobes. The oldest drift, deposited during the Kemuk Glaciation, is deeply weathered and completely buried by younger drift. Massive morainal embankments of the Clara Creek Glaciation, the second oldest and most extensive ice advance, have been greatly modified by erosion and masswasting, but sediments comprising them are less weathered than those of the Kemuk drift sheet. Moraines built during the successively less extensive Chagvan and Unaluk glaciations exhibit less modified constructional topography characterized by low arcuate ridges and numerous kettle lakes. Radiocarbon dates provide a minimum age for the Unaluk Drift of $8910 \pm 110$ years and for the Chagvan Drift of $>45,000$ years.

A broad bedrock channel buried beneath unconsolidated preglacial and glacial sediments was cut at a time when relative sea level stood 200 feet or more below its present position. Relationships of sedimentary fills to this and to a younger buried channel point to late Tertiary submergence of the Bering Shelf followed by eustatic changes related to fluctuations of Pleistocene glaciers.
\end{abstract}

RÉSUMÉ. Au voisinage de la baie Chagvan, les indices morphologiques et stratigraphiques révèlent qu'à au moins quatre reprises, des glaciers descendus des monts Ahklun se sont répandus sur les basses-terres côtières en formant de larges lobes de piedmont. La plus ancienne moraine, déposée au cours de la glaciation de Kemuk, est profondément altérée et complètement recouverte par de la moraine plus récente. Les berges morainiques massives de la glaciation de Clara Creek, la seconde en âge et la plus étendue des avancées glaciaires, ont été grandement modifiées par l'érosion et les mouvements de masse, mais les sédiments qui les composent sont moins altérés que ceux de la moraine de Kemuk. Les moraines construites durant les glaciations moins étendues de Chagvan et d'Unaluk montrent une topographie moins modifiée, caractérisée par des crêtes basses et arquées et de nombreux lacs de fonte (Kettle): les datations au radiocarbone assignent un âge minimum de $8910 \pm 110$ ans à la moraine d'Unaluk et de plus de 45,000 à la moraine de Chagvan.

Un large chenal, enfoui sous des sédiments préglaciaires et glaciaires nonconsolidés, a été creusé dans la roche en glace à une époque où le niveau de la mer se trouvait à 200 pieds $(60 \mathrm{~m})$ ou plus sous le niveau actuel. Les rapports entre, d'une part, les remblaiements sédimentaires et, d'autre part, ce chenal et un autre chenal fossile plus récent indiquent une submergence finitertiaire de la plateforme de Béring, suivie de changements eustatiques liés aux fluctuations des glaciers pléistocènes.

РЕЗЮМЕ. Оледенение в районе Чагванского залива на юго-западной Аляске. Морфологическе п стратиграфические привнаки в районе Чагванского залива указывалот на то, тто ледники, пентром которых являлись Аклунские торы, распространялись по прибрежной низменности по крайней мере четыре раза в виде пироких предгоршых допастей. Найболее древний и силљн выветрившийся делювий, отложивтийся во время кемукского оледенения, полностью покрыт делювием более позднего времени. Массивные моренные гряды, образовавшиеся во время кларакрикского оледенения, которое было вторым по счету п найболее обширным, сильно пзменены продессами выветривания и разрушения, но отложения здесь разрупались в меньшей степени, чем кемукский делювиальный покров. Морены, образовавшиеся в течение последующих и менее обпирных чагванского и уналукского оледенений, пмеют менее пзмененный структурный рельеф, характерной

1Department of Geology, University of Washington, Seattle, U.S.A. 
чертой которого являются низкпе дугообразнље гряды и многочисленные котловинные озера. Датировка радиоуглеродным методом покавала, что минимальный возраст уналукското делювия составляет $8910 \pm .110 \mathrm{\pi eT}$, а возраст чагванского дедювия превосходит 45000 лет.

Широкое речное русло, прореванное в коренных породах и погребенное рыхлыми доледниковыми и ледниковыми отложениями, обравовалось, когда относвтельный уровень моря находился по крайней мере на 200 футов ниже его теперешней отметки. Отнопение отложений к өтому и другому, более позднему погребенному руслу, указывает на затопление Љерннгова пельфа в конце Третичного периода с последующими әвстатическими изменениями, связанными с передвижениями плейстоденовых ледников.

\section{INTRODUCTION}

Widespread evidence of multiple glaciation in Alaska, gathered mainly during the last 15 years, has focused attention on the northwest corner of North America as a source of critical information on the Pleistocene climatic history of the Northern Hemisphere. In several key areas, the glacial record is supported by sufficient radiocarbon dates to establish detailed chronologies of late-Pleistocene glacial advances and permit correlations with dated glacial sequences from other parts of the continent. This paper summarizes evidence for multiple glaciation of an area formerly regarded as being largely nonglaciated. Several radiocarbon dates provide limiting ages which help to place the sequence delineated in this study within the broader framework of the Alaskan glacial record.

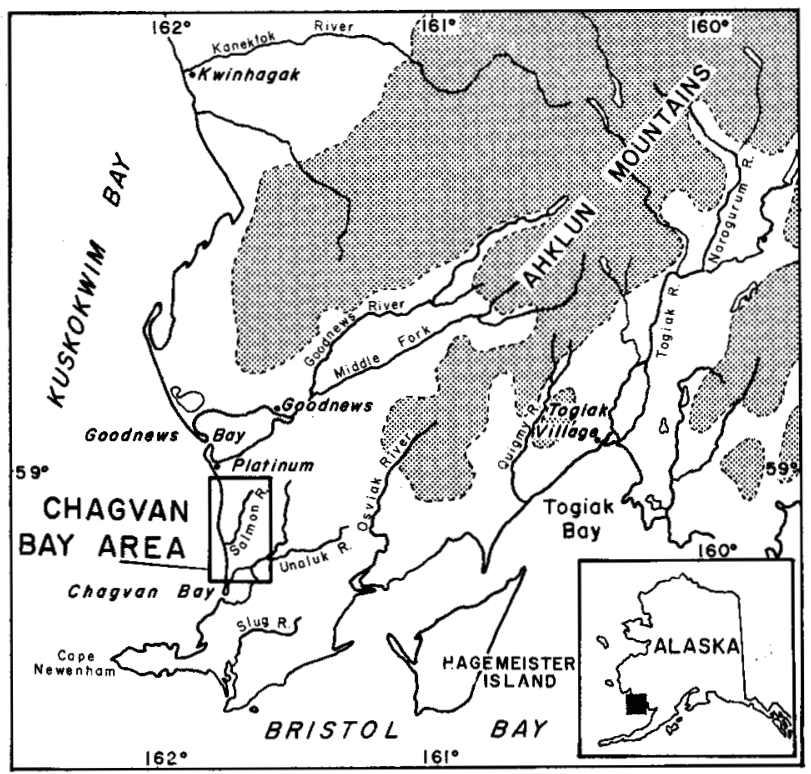

FIG. 1. Index map of southwestern Alaska showing location of Chagvan Bay area. Land areas above an altitude of 500 feet are shown by stippled pattern.

The Chagvan Bay area, as delimited in this paper, comprises approximately 75 square miles along the southeast side of Kuskokwim Bay in southwestern Alaska and includes most of the land between Chagvan and Goodnews bays (Fig. 1). The area of detailed mapping covers all land in the Hagemeister Island (D-6) 15-minute quadrangle with the exception of the extreme southeast corner, but a photogeologic study of adjacent areas to the south and east was made in order to extend the boundaries of drift sheets in those directions. Although much 
of the area lies close to sea level, local relief is impressive; Red Mountain, the highest summit in the vicinity, rises abruptly from sea level to an altitude of 1,887 feet. The Ahklun Mountains, which lie to the northeast, are a rugged glaciated upland reaching altitudes of more than 3,000 feet. The Salmon River is the principal stream draining the Chagvan Bay area and this study was concerned largely with the Pleistocene history of its valley. The northern part of the area is drained by the Smalls River, which flows into Goodnews Bay, and the region east of Chagvan Bay is drained by the Unaluk and Kinegnak rivers. Platinum, the largest community in the vicinity, is located immediately north of the map area at the southwest corner of Goodnews Bay. The camp of the Goodnews Bay Mining Company, situated at the junction of Platinum Creek and the Salmon River, constitutes the main settlement within the study area. A detailed description of the geography of the Chagvan Bay area is included in a report on the Goodnews platinum deposits by J. B. Mertie (1940).

Platinum placers along the Salmon River constitute one of the most important sources of platinum metals in North America and have been actively mined since the 1930's. The valley and several of its western tributaries have been extensively worked by dragline and dredge, which have left large piles of debris along the central 4.5 miles of valley floor.

The earliest work relating to the Pleistocene history of the region was a reconnaissance study in 1898 by J. E. Spurr (1900) who recognized and described glacial drift in the Ahklun Mountains along the Kanektok River drainage, in the vicinity of Togiak Lake, and along the shore of Togiak Bay. Spurr ascribed much of the drift, which was "characterized throughout by pebbles and bowlders scratched by ice," to marine and glacial-marine sedimentation "at a period when the sea stood at least 3,000 feet higher than at present." Hamilton (1921) subsequently found evidence that ice originating in the mountainous country east of Goodnews Bay had flowed out onto the coastal lowland near the bay. He suggested that glacier ice may have reached the sea in the Chagvan Bay area as well. The first study of the glacial deposits of the area immediately south of Goodnews Bay was conducted by Mertie (1940) in conjunction with his work on the placer deposits of the Platinum area. Although he considered the region around Chagvan Bay and the valleys of the Unaluk and Kinegnak rivers as nonglaciated, he interpreted unconsolidated sediments south of Goodnews Bay near the headwaters of the Salmon River and along the northwest side of Red Mountain as glacial drift and attributed them to deposition by a lobe of the "Goodnews Glacier" that had covered the site of Goodnews Bay. Mertie recognized only one stage of glaciation and believed that it corresponded "roughly to the Wisconsin stage in the northern United States." Surficial deposits and morainal features in the vicinity of Goodnews and Chagvan bays have recently been mapped, primarily through photointerpretation, by Hoare and Coonrad (1961a, 1961b), who assigned an early Wisconsin age to most of the glacial drift in the region.

The present investigation, carried out during the summer of 1963 , was concerned mainly with study of surficial sediments along the north side of Chagvan Bay, within the valley of the Salmon River, and along the coast of Kuskokwim Bay between the Salmon River and the town of Platinum. Except along the 
seacoast, where a wave-cut cliff exposes unconsolidated sediments almost continuously for eight miles, natural exposures are few and poor. Interpretation of the glacial history was based largely on study of surficial morphology and on records from numerous bore holes that have been drilled during the last several decades throughout most of the Salmon River valley. Recent artificial cuts resulting from dredging operations along the central part of the valley were useful locally in studying the sedimentary record of the valley fill.

\section{BEDROCK GEOLOGY}

The Chagvan Bay area is underlain by sedimentary, metasedimentary, and igneous rocks that range in age from Carboniferous to Tertiary (Mertie 1940; Hoare 1961; Hoare and Coonrad 1961b). The most widespread lithologic unit is the Gemuk Group, which includes from 15,000 to 30,000 feet of argilite, chert, greenstone, limestone, graywacke, tuff, and andesite and basalt flows. Some of the sediments have been locally metamorphosed to low- or medium-grade metasedimentary rocks that include slates, phyllites, and schists. These rocks, typical exposures of which are found along the south flank of Thorsen Mountain and on Kemuk Mountain, have been assigned ages ranging from Carboniferous through Jurassic. Small stocks and plug-like bodies of granitic, mafic, and ultramafic rocks intrude deformed strata of the Gemuk Group and have been assigned a probable Tertiary age by various workers. The largest is a body of serpentine, serpentinized dunite, and periodotite that underlies Red Mountain.

\section{UNCONSOLIDATED PREGLACIAL SEDIMENTS}

The oldest recognized unconsolidated sediments consist of deeply weathered gravel, sand, silt, and clay that overlie bedrock along the upper Salmon River valley and extend south beneath a cover of glacial drift to the vicinity of Chagvan Bay. Mertie (1940) probably included some of these sediments in his "older gravels." The strongly oxidized sediments were exposed in 1963 in fresh cuts near the southern limit of dredging operations in the Salmon River valley and were visible in tailings along the length of the valley. They also have been penetrated by numerous exploratory bore holes in the southern part of the valley. A deeply weathered sand-and-gravel unit exposed in a cutbank of the Salmon River immediately north of the mouth of Happy Creek may be part of this same body of sediment, but possibly it belongs to a deeply weathered glacial drift.

Stones within the oxidized sediments are in various stages of decomposition, some pebbles appearing fairly fresh and others having been completely weathered to clay. The general aspect of the sediments suggests that they have been chemically weathered over a long period of time.

Deeply weathered bedrock has been exposed locally beneath approximately 10 feet of strongly oxidized gravel in cuts at the north end of dredging operations in the Salmon River valley. The upper 3 to 4 feet of bedrock are noticeably altered and decomposed, but with increasing depth the intensity of alteration diminishes. Bedrock taken from deep bore holes in the southern part of the valley is also strongly weathered, most samples having been converted to clay. 
According to Mertie (1940), ultramafic rocks in the area were intruded during the late Cretaceous or early Tertiary. Hoare and Coonrad (1961b) assigned them a Tertiary age. Inasmuch as the oxidized gravels contain ultramafic clasts, the gravels must postdate the intrusives. The oxidized sediments, in turn, are overlain by Pleistocene glacial drift; hence, they are broadly assigned an age of post early Tertiary and preglacial.

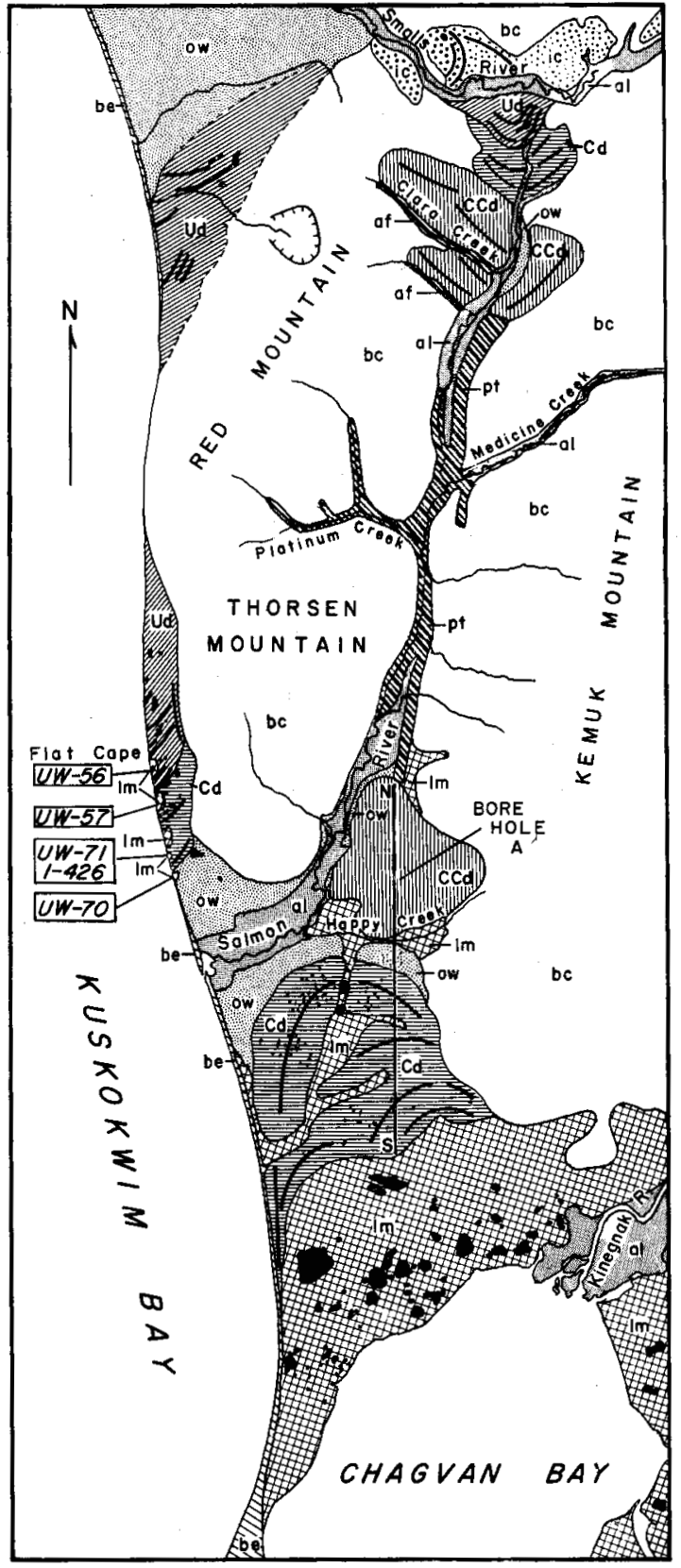

EXPLANATION

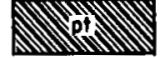

PLACER TAILINGS

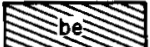

BEACH SEDIMENTS

a

A LLUVIU M

80

LAKE \& MARSH SEDIMENTS

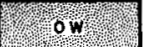

OUT WASH (UNDIFFERENTIATED)

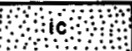

ICE-CONTACT GRAVELS

率ud - Unaluk drift

ECd - Chogran drift

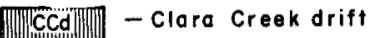
UNDIFFERENTIATED DRIFT

(LARGELY TILL) FORMING END AND GROUND MORAINE

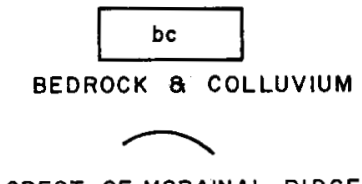

CREST OF MORAINAL RIDGE
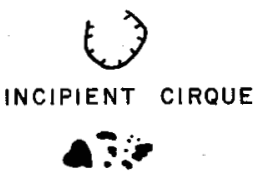

SHALLOW LAKES

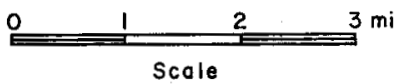

FIG. 2. Surficial geologic map of Chagvan Bay area. 


\section{GLACIAL SEQUENCE}

Mertie (1940) found evidence that glacier ice had entered the headwaters of the Salmon River and reached altitudes of more than 800 feet along the northwest side of Red Mountain. However, he recognized no evidence of glaciation in the southern Salmon River valley or around Chagvan Bay and therefore believed that ice had been restricted to the region about Goodnews Bay.

Hoare and Coonrad (1961b), like Mertie, recognized that the north end of the Salmon River valley and the coastal region along the northwest side of Red Mountain had been glaciated, but farther south they placed the limit of glaciation well east of Chagvan Bay. Mainly on the basis of photointerpretation, they mapped outwash sediments extending west to Chagvan Bay from a morainal border to the east.

The present investigation disclosed that glacier ice had invaded the Chagvan Bay area from the east and had pushed north into the lower part of the Salmon River valley. Four recognized drift sheets are designated, from oldest to youngest, Kemuk, Clara Creek, Chagvan, and Unaluk.

\section{Kemuk drift}

The Kemuk drift sheet, which lies deeply buried beneath younger drift near the southwest base of Kemuk Mountain, is known only from a single deep bore hole at the crest of a hill half a mile north of Happy Creek (designated Bore Hole A in Figs. 2 and 3). Three principal stratigraphic units were recognized in sediments recovered from this hole: a lower unit, consisting of strongly oxidized preglacial sediments which overlie weathered bedrock; a middle unit, consisting of oxidized sand, silt, and till, that comprises the Kemuk Drift; and an upper unit, consisting of slightly oxidized till, sand, and gravel, that constitutes the Clara Creek Drift. Because a continuous core was not taken, reported thicknesses of stratigraphic units are approximate:

\section{Unit Lithology}

\section{Clara Creek Drift}

15. No record (probably largely weathered sandy gravel) . . . . . 29

14. Pebble-cobble gravel ...................... 4

13. Compact stony till; stones weathered and disintegrated ..... 3

12. Transition zone including till and gravel ............. 6

11. Sand and gravel ......................... 11

10. Till (?) .............................. 2

9. Sand and gravel ...................... 9

8. Compact stony till; contains striated cobbles ........... 2

7. Greenish-gray gravel and sand ............... 11

6. Till; striated stones in unweathered clay-rich matrix; some deeply weathered stones probably in part derived from underlying units 
Kemuk Drift (decreasing intensity of oxidation from top to bottom)

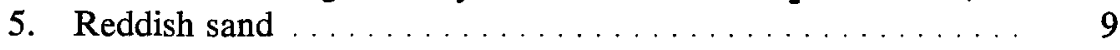

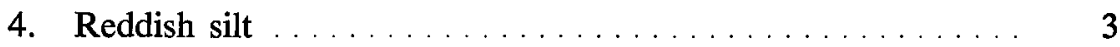

3. Stony till; most stones deeply weathered $\ldots \ldots \ldots \ldots \ldots \ldots r$

2. Gravel and sand, slightly oxidized $\ldots \ldots \ldots \ldots \ldots \ldots \ldots .12$

Thickness of Kemuk Drift $\ldots \ldots \ldots \ldots \ldots \ldots \ldots, \frac{12}{32}$

Preglacial sediments

1. Gravel, sand, and silt; strongly oxidized; stones completely decomposed at some horizons ................. 90

Bedrock

Thickness of preglacial sediments $\ldots \ldots \ldots \ldots \ldots \ldots \quad \overline{90}$

Metasedimentary rock; disintegrated and almost completely altered to yellowish-orange clay $\ldots \ldots \ldots \ldots \ldots \ldots \ldots \ldots, 1+$

Identifiable Kemuk Drift was not seen beyond the limit of Clara Creek Drift, which may mean that Kemuk ice reached no farther north in the lower Salmon River valley than did ice of the Clara Creek Glaciation. That much or all of the central part of the valley was glaciated during the Kemuk Glaciation remains a distinct possibility, however, even though convincing evidence for this was not found. The apparent continuity of oxidized preglacial gravels suggests that if the entire valley was glaciated at that time, the ice was probably thin and the amount of erosion minimal.

Strong oxidation of the Kemuk Drift suggests a long period of chemical weathering preceding deposition of the overlying drift sheet. The total depth of weathering is not known because Kemuk Drift is separated from Clara Creek Drift by an erosional unconformity, above which an unknown thickness of weathered Kemuk sediments was removed by advancing Clara Creek ice.

\section{Clara Creek Drift}

Clara Creek Drift is named for a northern tributary of the Salmon River which flows between subdued end-moraine ridges of this drift sheet. Drift of Clara Creek age underlies the surface between Dowry Creek and the broad divide separating the Smalls River and Salmon River drainages, but because exposures are rare little is known about the physical character of the drift. Clara Creek Drift is also found between Happy Creek and the southern limit of placer-dredging operations; three or four probable tills are included in the Clara Creek drift sheet where

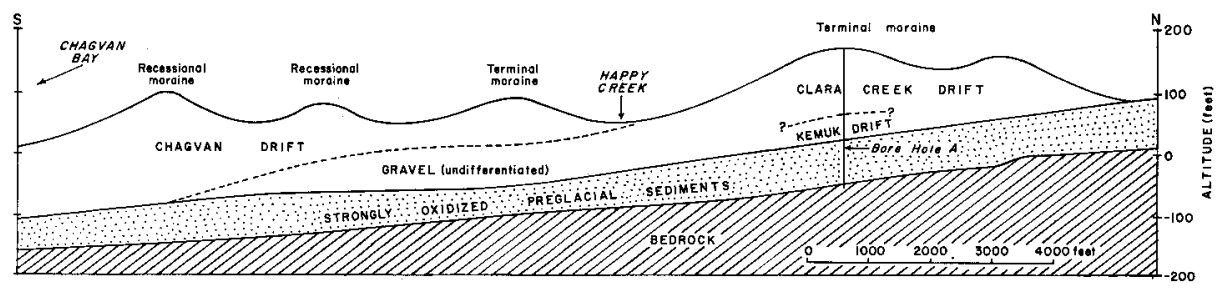

FIG. 3. North-south section through Clara Creek and Chagvan moraines at lower end of Salmon River valley based on bore-hole records. 
penetrated by Bore Hole A (Figs. 2 and 3). The drift is exposed locally in cutbanks along the Salmon River immediately north of the mouth of Happy Creek, and drift of possible Clara Creek age crops out beneath younger outwash gravels in sea cliffs north of the mouth of the Salmon River.

Morainal topography is obscure, owing to the advanced degree of mass-wasting, to erosion, and to a thick cover of tundra vegetation. The northern lobe of Clara Creek Drift in the upper end of the Salmon River valley preserves some faint morainal topography, but any initial surface irregularities have been smoothed out by extensive slope movement. A prominent compound ridge up to 250 feet high that lies between the southwest end of Kemuk Mountain and the south end of Thorsen Mountain is an end moraine of the Chagvan Bay glacier lobe. Although almost unrecognizable as a moraine because of substantial erosion and mass-wasting, it is an anomalous topographic feature in that it does not conform to any known bedrock structure, and can satisfactorily be explained only as a morainal embankment. Exposures of drift along the Salmon River at the western end of the highest ridge support this interpretation, as does sediment recovered from several bore holes that penetrated the moraine.

From bore-hole data, it is possible to show in a geologic section (Fig. 3) the inferred thickness of Clara Creek Drift near the centre of the Salmon River valley along a line that passes through the axial part of the massive end moraine. A maximum measured thickness of 105 feet occurs along this line. The height of the largest of the two morainal ridges is due in part to the presence of Kemuk Drift, which was overriden and buried by advancing Clara Creek ice.

Clara Creek sediments are less decomposed than those of the underlying Kemuk Drift, but they include volcanic rocks that are easily disaggregated, suggesting appreciable weathering. Other rock types are much firmer and have only thin weathering rinds. A manganese oxide coating is characteristic of many volcanic stones in gravels of Clara Creek age.

A fabric measurement of stony Clara Creek till exposed near the mouth of Happy Creek shows a strong orientation of long axes of stones in the direction N. $35^{\circ} \mathrm{W}$, which is inferred to represent the direction of ice movement at the time of till deposition. Till stones from this exposure are mainly phyllites and schists, but some sedimentary rock types are also present. Igneous clasts are conspicuously absent. Had the source of the till stones been the Salmon River drainage, ultramafic rocks characteristic of that drainage should be present in some abundance; on the other hand, if the source lay east of Chagvan Bay, ultramafics should be rare or absent. The fabric and lithology of the till therefore support the contention that ice moved west into the region of Chagvan Bay and pushed north in the lower Salmon River valley during the maximum Clara Creek advance.

\section{Chagvan Drift}

Chagvan Drift is named for Chagvan Bay, the northern perimeter of which is bounded by moraines of this drift sheet. Chagvan Drift underlies the land surface in the upper Salmon River valley, and in most of the region between the head of Chagvan Bay, Happy Creek, and the mouth of the Salmon River; drift 
of possible Chagvan age lies at the southwest base of Thorsen Mountain. Exposures are limited almost entirely to cutbanks along the lower part of the river and to cliffs along the coast, but the drift sheet has also been penetrated by numerous bore holes south of Happy Creek. Records from these holes have provided data on the subsurface distribution and thickness of the drift.

End moraines built by Chagvan ice, although low and displaying few topographic irregularities, are nevertheless recognizable morphologic features that constitute a series of arcuate ridges at both ends of the Salmon River valley. North of Chagvan Bay morainal crests commonly rise 50 to 75 feet above sea level, with the highest ridges reaching altitudes of 100 feet. Moraines occupying the Salmon River-Smalls River divide lie at altitudes of 250 to 350 feet. In both areas, moraines have been considerably modified by mass-wasting and, to some extent, by erosion. Those immediately north of Chagvan Bay are almost completely vegetated so that little sediment is exposed. Numerous small kettle ponds dot the surface. The moraines at the head of the Salmon River valley, though smaller, are comparable to those farther south, except that kettle ponds are absent. A narrow belt of moraine, possibly Chagvan in age, at the southwest base of Thorsen Mountain closely resembles the moraines at the two ends of the Salmon River valley and contrasts with fresher-appearing moraine immediately to the north. The ground surface has a dense cover of tundra vegetation, and several subdued arcuate morainal ridges that trend northeast parallel the margins of the exposed drift sheet. Several small ponds lie in closed depressions on the surface, and bog sediments exposed in sea-cliff exposures rest on oxidized till. Till and gravel underlying the surface are commonly iron-stained, and iron-oxide cement has locally produced a high degree of induration. Most volcanic stones have thin rinds, but some are weathered to the core. Locally, both till and gravel have been strongly deformed into tight folds and steep faults.

Drill-hole information from the area between Happy Creek and the head of Chagvan Bay shows that Chagvan Drift decreases in thickness progressively northward toward the drift border (Fig. 3). The maximum inferred thickness of the drift sheet along the constructed section is $\mathbf{1 7 5}$ feet; the average thickness is probably between 50 and 100 feet. South of the last prominent recessional ridge, Chagvan Drift lies directly on oxidized preglacial sediments, but to the north it overlies younger gravels. These gravels may belong largely to the Clara Creek drift sheet, but very likely they also include some preglacial Chagvan outwash.

Outwash from the Goodnews Bay glacier, which entered the headwaters of the Salmon River, was carried south and became interstratified with outwash grading seaward from the Chagvan Bay lobe and with proglacial outwash from ice that flowed south along the west side of Thorsen Mountain. An abandoned meltwater channel through the apex of the terminal moraine south of Happy Creek is coextensive with outwash gravels that have a westward gradient around the northwest edge of the moraine. Outwash deposited during the maximum stand of this advance is exposed in several cutbanks between the mouth of the Salmon River and the mouth of Happy Creek. Coastal exposures north of the Salmon River show sections of a preglacial outwash fan that was built south and east along the southwest base of Thorsen Mountain. Outwash from the northern ice 
lobe is visible in tailings along the axis of the Salmon River valley north of Happy Creek.

\section{Unaluk Drift}

Unaluk Drift is named for the Unaluk River, which follows the northern margin of this youngest recognized drift sheet before joining the Kinegnak River and entering the northeast corner of Chagvan Bay. At the latitude of Chagvan Bay, the western margin of the drift lies about 4 miles east of the bay; however, ice of the Goodnews Bay lobe reached the Salmon River-Smalls River divide and also extended south along the coast to a point about 2 miles north of the mouth of the Salmon River. Both the Salmon River valley and Chagvan Bay remained free of ice during the Unaluk Glaciation.

East of Chagvan Bay, end moraines of Unaluk age are very fresh, having been little altered by erosion or mass-wasting. Kettle-and-kame topography is widespread, and numerous lakes and ponds fill closed depressions within the morainal belt. An extensive outwash plain that was built west toward Chagvan Bay and toward the headwaters of the Slug River has been dissected and terraced by postglacial stream action. A thin mantle of eolian sediment that overlies much of the area was probably deposited during the Unaluk Glaciation by winds that blew west off the glacier and reworked fine-grained sediments on the surface of the outwash plain.

Fresh gravelly arcuate moraines lie close to the crest of the divide separating the Salmon River and Smalls River drainages. Behind them, in the valley of the Smalls River, are abundant gravels, apparently ice-contact in origin, deposited during recession of the glacier. Little outwash is visible along an abandoned meltwater channel that leads south into the Salmon River valley from the outermost morainal ridge. The glacier probably stood at this maximum position too short a time for much sediment to accumulate.

Arcuate moraines of Unaluk age are also found along the coastal bench below the west flank of Thorsen Mountain and the northwest side of Red Mountain. Sediment comprising them is continuously exposed in sea cliffs for several miles along the coast. Some morainal ridges may have resulted largely from ice-shove, for bedded gravels underlying them have been asymmetrically folded by an apparent movement from the north or northwest. These moraines are interpreted as products of minor readvances by the Goodnews Bay glacier during deglaciation.

Several shallow basins between ridges of recessional moraine along the coast are filled with water, but others have been drained as cliff recession has progressed inland. Sediments within these basins consist of fine sand, silt, and clay, with interstratified organic layers, and commonly rest directly on till or associated recessional outwash gravels.

Where seen in sea-cliff exposures, till of Unaluk age is commonly very stony, bluish-gray, and appears fresh and unweathered. Associated sand and gravel also is fresh, and although slight oxidation has imparted a brownish hue to the sediments, weathering rinds on stones are very thin or are absent.

Three small cirques on the north flank of Jagged Mountain near Cape Newenham provide evidence of local glaciation southwest of Chagvan Bay. Their floors 
lie at altitudes of 1,000 to 1,100 feet. Although the cirques were not examined in the field, aerial photographs indicate that each contains piles of rubble that appear to be morainal. One cirque contains two morainal features, possibly recording two different glaciations. The shapes of the valleys beyond the cirques indicate that glaciers formerly extended well beyond cirque thresholds. The apparent freshness of the cirques and moraines suggests that the cirques were occupied by glacier ice during the Unaluk Glaciation.

A broad, shallow, theatre-like depression on the northwest flank of Red Mountain may be an incipient cirque. Although it has no well-defined floor, the lower limit of the feature lies close to 1,000 feet. The depression was probably occupied by ice or by a perennial firn bank during much of the last glaciation.

\section{BURIED BEDROCK CHANNELS}

Buried bedrock topography, reconstructed from bore-hole data, indicates the presence of two buried channels in the Salmon River valley. An eastern channel, which extends south from the vicinity of Medicine Creek toward the north end of Chagvan Bay, ranges in width from about 1,000 feet in its upper part to half a mile or more near Chagvan Bay. The channel is floored by deeply weathered and decomposed bedrock and is overlain by oxidized preglacial sediments. Clearly, it represents a preglacial channel of the Salmon River cut at a time when the river flowed south toward what is now Chagvan Bay.

A western channel coincides rather closely with the present channel of the Salmon River. This sharp, V-shaped gorge, nowhere more than 500 feet wide, is incised in fresh unweathered bedrock and is overlain by nonweathered gravels of glacial origin. Mertie (1940, p. 7) traced a branch of this channel two miles up the valley of Medicine Creek. A similar tributary channel was traced half a mile up the valley of Platinum Creek, at which point it abruptly terminated. The northward extent of the western channel is not known. Possibly it continues as far as the mouth of Clara Creek, and it may extend up that creek for some distance as well. Drill-hole information is not available along the entire course of the Salmon River, but the path of the buried western channel is rather closely delimited, south of the river, by the axis of a buried bedrock high that has been defined by geophysical surveys, and by the adjacent south-facing bedrock slopes of Thorsen Mountain. The buried channel probably coincides closely with the position of the present river channel at the coast.

The western buried channel has a rather uniform gradient throughout its length, except for a slight steepening at -70 feet. Assuming that the gradient of this channel remains constant beyond the limit of subsurface information, the channel floor would lie 100 feet below sea level in the vicinity of the present coastline. The gradient of the eastern channel is steeper than that of the western channel. Although the gradient of its lower part is comparatively uniform, irregularities in the long profile appear north of Happy Creek. The channel floor has been traced to within a mile of the north shore of Chagvan Bay, where it lies 160 feet below sea level. Extrapolation of the profile toward the bay places the channel floor some 200 feet below sea level at the north shore. Subsurface data on bedrock configuration along the northwest side of the bay suggests that the eastern 
channel may enter a major west-trending buried channel near the middle of the bay, where the bedrock surface lies at least 250 feet below sea level.

The buried eastern channel antedates the deeply oxidized sediments overlying it, which are regarded as post-early Tertiary and preglacial in age. If the floor of the channel descends to depths of at least 200 feet below sea level, as suggested above, sea level at the time of channel-cutting must have stood some 200 feet or more below its present position in relation to the land.

The buried western channel is clearly much younger. Both the bedrock flooring the channel and the overlying gravels appear fresh and little weathered. The sharply incised channel was probably cut during one or more periods of lowered sea level that coincided with Pleistocene glaciation. If the offshore profile was steeper than the long profile of the stream, as is the case today, each lowering of sea level would have resulted in rejuvenation and downcutting by the river. Removal of sedimentary valley fills would have been followed by excavation of bedrock and steepening of channel gradients. Although no satisfactory way was found to date the inception of channel excavation, it seems likely that downcutting was in progress during each of the major glaciations recognized in this area. The channel, therefore, may not date to any single glaciation, but may be the composite product of several periods of excavation.

\section{POSTGLACIAL COASTAL RECESSION}

A pronounced bench, commonly ranging in altitude from 20 to 50 feet, is present along most of the strip of coast between the mouth of the Salmon River and the southwest corner of Goodnews Bay. It is absent only along the southwest base of Red Mountain, where bedrock rises steeply above the beach. The bench maintains a fairly uniform width south of this point, but northwest of Red Mountain it widens considerably and rises gradually eastward toward the valley of the Smalls River. Sea-cliff exposures indicate that throughout its length the bench is underlain by unconsolidated glacial sediments, mainly till, sand, and gravel, most of which date from the last glaciation.

That the nearly flat bench is a surface neither of marine deposition nor of marine erosion is suggested by the absence of marine sediments or fossils on it, and by undisturbed organic-rich lacustrine sediments that rest directly on till without intervening marine sediments. The relatively unmodified surface topography of the bench, which consists of constructional features of the youngest drift sheet, together with stratigraphic evidence from sea-cliff exposures, indicates that the bench is largely morainal in origin.

The most probable origin of the sea cliff fronting the bench seems to be progressive recession resulting from strong and persistent wave action along the coast. The profile of the gravel outwash surface immediately northwest of Red Mountain, if extrapolated in the seaward direction, intersects present sea level a mile west of the coastline. Therefore, if the original depositional gradient of the outwash surface was uniform in that direction, at least a mile of cliff recession has occurred along this stretch of coast in postglacial time. Very likely, the rate of recession was rapid at first, but slowed down as the sea cliff became progressively higher. There can be little doubt that the coast is being vigorously eroded 
today. Small Japanese glass fishing floats were found as far as 100 yards inland from the edge of the bench, which rises 20 to 30 feet above the present beach. They were evidently tossed there by storm waves that must expend considerable energy in eroding the unconsolidated sediments exposed above the beach.

\section{SUMMARY OF PLEISTOCENE HISTORY}

The configuration of the eastern buried channel of the Salmon River valley suggests that in preglacial times the river flowed south and possibly joined a major trunk stream that flowed west through the area of Chagvan Bay. The steep profile of the channel indicates that at the time of channel cutting the stream was graded to a relative sea level considerably below that of today. That period, which preceded deposition of the preglacial unconsolidated sediments along the valley, must have been a time when southwestern Alaska and adjacent areas of the Bering Sea floor were largely or entirely emergent. According to Hopkins (1959), the region of the Chukchi and Bering seas lay above sea level throughout most of the middle and late Tertiary. Sometime after the middle Pliocene, but prior to the Pleistocene Epoch, the Bering-Chukchi Platform sank and was inundated by the sea. Rising sea level must have brought about alluviation in many valleys which were not completely submerged. The preglacial oxidized sediments that overlie the eastern channel of the Salmon River valley very likely date to this period of alluviation and their age may therefore be late Pliocene, early Pleistocene, or both. Strong weathering of the sediments and decomposition of bedrock along the channel point to an extensive period of weathering after alluviation and before the first recognized glacial advance. The intensity of chemical weathering suggests that during that period the climate may have been milder than it is today.

During the earliest recognized glaciation, a large ice lobe moved into the Chagvan Bay region from the east and occupied at least the lower part of the Salmon River valley, possibly damming or diverting the south-flowing river. In the broad lower reaches of the valley, the upper part of the oxidized sediments comprising the valley fill was eroded and drift was deposited unconformably upon the older sediments. The ice did not scour to bedrock in the vicinity of Happy Creek, but it may have done so elsewhere in the lower part of the valley. Although evidence of Kemuk Glaciation has not been identified in the northern part of the valley, probably the region of Goodnews Bay also was glaciated at that time.

Following recession of the glacier, Kemuk Drift was deeply weathered during the succeeding interglaciation. The deep weathering profile on the drift sheet suggests a long interval of mild climate during which chemical weathering was more important than it is at present.

Renewed glaciation, accompanied by lowering of sea level, caused the Salmon River to entrench itself in unconsolidated Kemuk sediments and, ultimately, in the bedrock floor beneath. The Clara Creek Glaciation was the most extensive of those recognized. Nearly all of the Goodnews Bay and Chagvan Bay areas were inundated by ice, except for the central part of the Salmon River valley, which remained largely free of ice between adjacent glacier lobes. During its maximum advance, the Goodnews Bay glacier entered the headwaters of the Salmon River, 


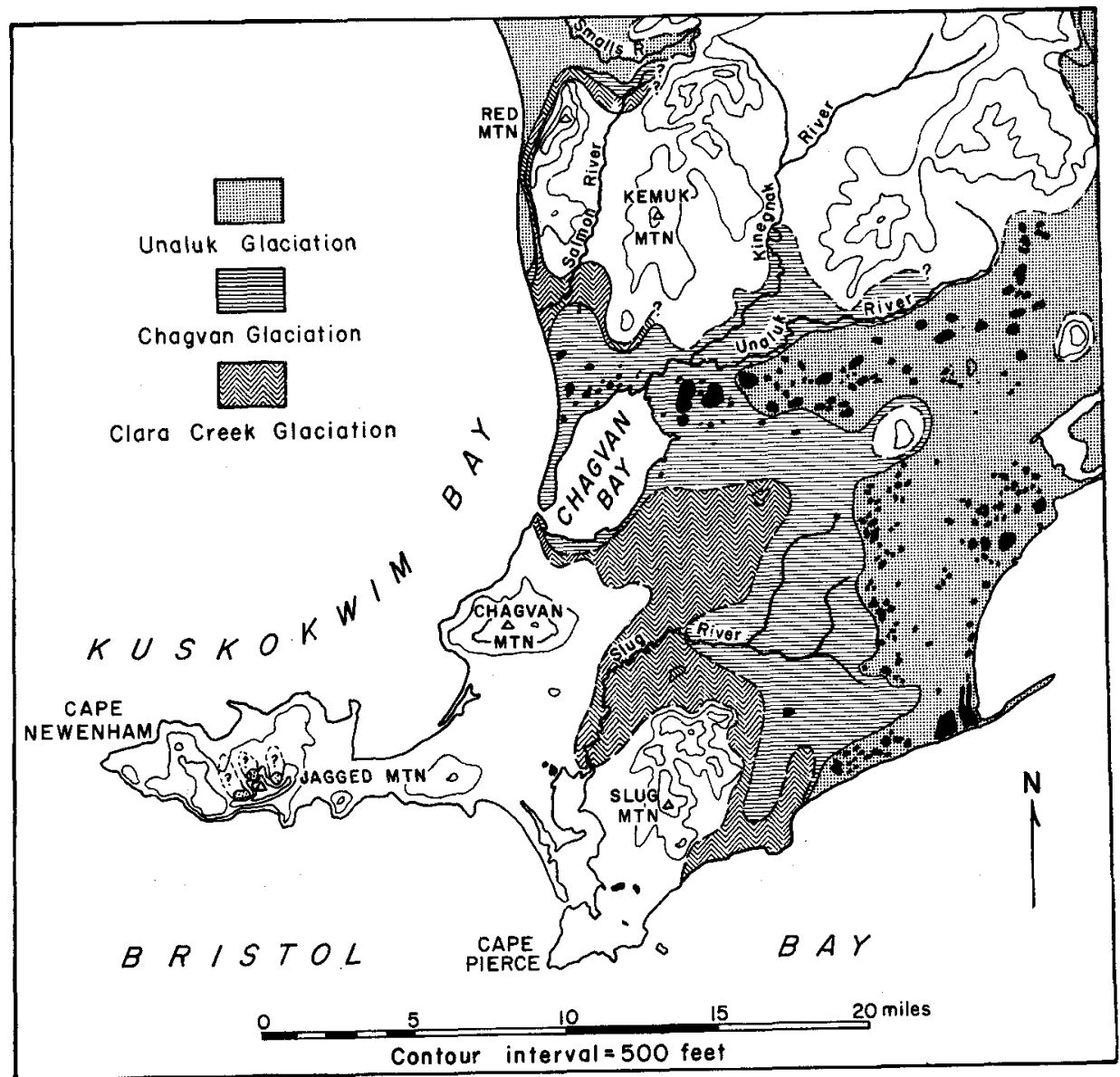

FIG. 4. Inferred limit of ice during Unaluk, Chagvan, and Clara Creek glaciations. Based largely on photointerpretation beyond Chagvan Bay area. Dashed boundaries only approximately located.

and ice in the region of Chagvan Bay flowed north into the lower reaches of the Salmon River valley, the two lobes approaching within 4.5 miles of one another (Fig. 4). At that time, south-draining meltwater in the valley must have been ponded by the Chagvan Bay lobe. Although evidence of this inferred ponding was not seen in the exposed valley deposits, lacustrine sediments that formed during such an interval may have been completely removed by subsequent erosion or may lie buried beneath younger deposits along the valley margins. Possibly the period of ponding was so brief that little sediment accumulated between the opposing lobes.

Ice moving west and south from the Goodnews Bay area must have encroached upon the northwest flank of Red Mountain. Glacial erratics noted by Mertie at altitudes above 800 feet on the northeast ridge of the mountain may date from this glaciation. No evidence was seen in the headwaters of Platinum Creek to suggest that Clara Creek or younger ice flowed over the low divide (700 feet) 
at the head of this creek and entered the Platinum Creek drainage, so at that point Clara Creek ice was probably thin. However, ice of the Goodnews Bay lobe may have extended south to Flat Cape, or beyond, and coalesced with ice of the Chagvan Bay lobe near the present mouth of the Salmon River, forming a more or less continuous piedmont ice sheet.

With retreat of the glacier, large morainal accumulations were left at each end of the Salmon River valley. The thick morainal embankment at the south end of the valley forced meltwater to take a marginal course. Abandonment by the Salmon River of its preglacial course to Chagvan Bay dates at least to the Clara Creek Glaciation, and possibly to the Kemuk Glaciation.

Glaciers of the Chagvan advance were less extensive than those of the Clara Creek Glaciation, for although the Chagvan Bay lobe moved into the lower Salmon River valley and overrode older drift, it did not completely block the lower end of the valley (Fig. 2). Ice from the Goodnews Bay lobe moved into the valley of the Smalls River and just overtopped the low divide separating it from the Salmon River drainage. It also flowed south along the west side of Red Mountain, but apparently did not coalesce with the Chagvan Bay glacier.

The subsurface relations inferred from bore-hole data suggest that in the immediate vicinity of Chagvan Bay, Chagvan ice scoured deeply and largely removed drift of earlier glaciations; near its northern margin, probably owing to thinning of the glacier and an uphill gradient, little erosion seems to have taken place, and there the terminal moraine rests on buried drift which is probably of Clara Creek age. This relationship is similar to that between Clara Creek Drift and the older Kemuk Drift, except that the Kemuk drift sheet appears to have been completely overridden and buried. Available information suggests that during none of the three oldest recognized glaciations did ice erode down to bedrock along the axial portion of the Salmon River valley north of Chagvan Bay.

As the glaciers grew and sea level fell, the Salmon River again began to degrade the sedimentary fill of its valley. Meltwater originating near the head of the Smalls River was probably diverted into the headwaters of the Salmon River along an ice-marginal course. Gravelly outwash filled the recently re-excavated bedrock gorge in the Salmon River valley and merged with outwash from the Chagvan Bay glacier to the south.

Ice retreat involved a series of halts, during which arcuate recessional moraines were built behind the outermost morainal ridge in both the upper and lower parts of the Salmon River valley. In the time since Chagvan glaciers left the area, masswasting has modified the moraines by smoothing out topography and reducing relief, but little erosion of Chagvan Drift has occurred, except along the coastal sector.

During the Unaluk Glaciation, ice flowed down the valley of the Unaluk River, but did not reach Chagvan Bay. An extensive outwash plain was built out from the ice margin, which lay approximately 4 miles east of the bay (Fig. 4); probably much of the submerged land under the bay is underlain by outwash. Farther north, ice invaded Goodnews Bay and pushed south along the northwestern and western flanks of Red Mountain and Thorsen Mountain, spreading out as a piedmont lobe in the coastal lowlands, but at its maximum extent it did not reach 
as far as the present mouth of the Salmon River. A small ice lobe entered the Smalls River drainage and barely overtopped the Smalls-Salmon divide. Moraines built there are small, and little or no outwash is present along the Salmon River valley beyond, suggesting that the ice remained in this terminal position for only a brief time. Sea level again fell, causing the Salmon River to entrench itself in the valley fill and possibly into bedrock. Retreat of the ice was punctuated by halts and readvances that are recorded by a series of small recessional moraines on the north side of the Smalls-Salmon divide. Large arcuate end moraines on the north side of Goodneys Bay (Hoare and Coonrad 1961a) may also be Unaluk recessional moraines of the Goodnews Bay glacier. Ice-contact gravels in the Smalls River valley indicate stagnation and wastage of the Goodnews Bay lobe as the ice continued to diminish in volume and areal extent. Extensively kettled drift east of Chagvan Bay indicates comparable stagnation there. The deposits reflect a marked change in glacier regimen that may have been caused by a major change in climate.

With final dissolution of the glaciers, stream regimens changed and postglacial dissection and terracing of the youngest outwash bodies began. Waves generated by prevailing southwesterly winds eroded unconsolidated glacial and postglacial deposits along the coast causing significant recession of the shoreline. The bulk of these sediments, reworked by longshore currents, have been deposited as spits across the mouths of Chagvan and Goodnews bays. The bays, in turn, appear to be slowly filling with fine-grained sediments carried to them by major streams.

\section{AGE AND CORRELATION OF DRIFT SHEETS}

Estimates of the age of the drift sheets were arrived at by comparing degree and depth of weathering and extent of postglacial modification by mass-wasting. The evidence indicates a marked break in characteristics between the two younger and the two older drifts. The Unaluk and Chagvan drifts are comparatively fresh and have shallow weathering profiles. Most incorporated stones are unweathered or have thin oxidation rinds. Although Chagvan moraines have been considerably smoothed by mass-wasting, and kettle lakes have been largely filled with sediment, the moraines are nevertheless readily recognizable and retain most of their original constructional morphology. Absence of an appreciable weathering profile on the Chagvan Drift suggests that it does not antedate the Unaluk Drift by a large time span and that the nonglacial interval separating the two advances may not have been a full interglaciation.

Chagvan Drift, on the other hand, contrasts sharply with Clara Creek Drift, in which the weathering profile extends to several tens of feet and most included volcanic stones are so strongly weathered that they disaggregate readily. Furthermore, the moraines have been so greatly modified by mass-wasting that they are scarcely recognizable as morainal. These characteristics suggest a full interglacial interval between deposition of Clara Creek and Chagvan drifts.

Kemuk Drift, known only from a single bore hole, is more intensely oxidized than Clara Creek Drift and its included stones are strongly weathered. Total depth of the weathering profile cannot be determined because an unknown thickness of Kemuk Drift was eroded during the Clara Creek Glaciation. Although at first 
glance the basal till of the Clara Creek Drift appears strongly weathered, only the included stones are appreciably altered, and these were probably derived largely from the underlying weathered Kemuk Drift. Gravel and sand overlying this basal till are virtually unoxidized and show little or no indication of weathering. The intensity of oxidation of Kemuk Drift suggests that a major interglacial, possibly of long duration and perhaps characterized by very mild climate, separated the Kemuk and Clara Creek glaciations.

Five radiocarbon samples collected from basal peat in bogs exposed in sea cliffs near Flat Cape provide limiting dates for part of the glacial sequence:

Sample

UW-70

UW-71

I -426

UW-57

UW-56

\section{Locality}

1.2 miles north of mouth of Salmon River

1.3 miles north of mouth of Salmon River

1.3 miles north of mouth of Salmon River

1.6 miles north of mouth of Salmon River 1.9 miles north of mouth of Salmon River
Date (years B.P.)

$12,840 \pm 170$

$12,110 \pm 130$

$11,500 \pm 250$

$>45,000$

$8,910 \pm 110$

Through a distance of 1.7 miles north of the mouth of the Salmon River, sediments are considerably more iron-stained and locally more highly indurated than drift farther north, suggesting that the change in character of the sediment marks the boundary between drifts of Unaluk and Chagvan age. Also, surface morphology is more subdued and deformation of sediments appears greater south of this point. Sample UW-57, collected from basal peat in a bog immediately south of the boundary, was beyond the range of radiocarbon dating, and implies considerable antiquity for the underlying till. However, 3 peat samples (I-426, UW-70, UW-71) from two filled depressions farther south are appreciably younger, an apparently anomalous situation if the underlying drift is essentially of the same age throughout its area of exposure, as field relations seem to indicate. Several alternative explanations for the apparent anomaly must be considered: (1) The age of sample UW-57 is spuriously old, because of laboratory error. This explanation appears unwarranted and the remaining alternatives therefore rest on the assumption that all reported dates are correct.

(2) Sample UW-57 was contaminated with very old, redeposited organic matter. Inspection of the sample before submitting it to the laboratory showed no obvious evidence of such redeposition. Furthermore, the geographic location of the sampling site relative to adjacent areas from which older organic matter might have been derived in sufficient quantity to affect the age of the sample tends to preclude this possibility.

(3) The depression on Chagvan Drift from which sample UW-57 was collected is surrounded by Unaluk Drift. Had the Goodnews Bay glacier surrounded this locality during the Unaluk Glaciation, it seems very likely that the depression would have been buried beneath outwash sediments, which is not the case. Drift south of the sample site is noticeably more iron-stained than that to the north, as noted above, suggesting that only Chagvan Drift lies to the south.

(4) Samples UW-70, UW-71, and I-426 do not represent the oldest peat in the depressions from which they were collected because the age of the lowest exposed 
peat is a function of cliff recession: assuming a more or less symmetrical basin, the first exposed peat would tend to be relatively old, having been deposited along the shallow margin of the basin, but it very likely would not be the oldest peat (Fig. 5). As Potzger (1956) has pointed out, the oldest peat commonly lies in the deepest part of the basin, which may or may not be centrally located. The

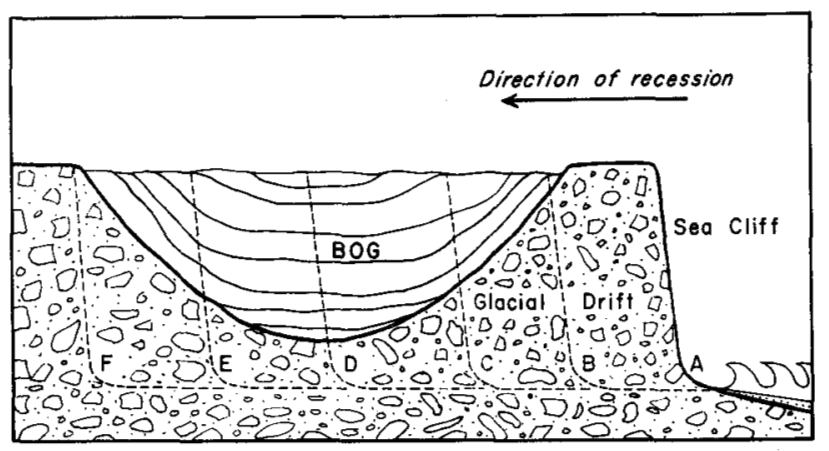

FIG. 5. Diagrammatic section through peat-filled depression illustrating variation in age of lowest exposed peat during sea-cliff recession. Oldest peat is exposed only in profile $\mathrm{D}$, whereas in profiles $B, C$, and $E$, basal peat is of intermediate age. Closest minimum age for underlying drift is provided by date on basal peat from profile D.

oldest part of the organic accumulation could be sampled in the sea cliff only when cliff recession had caused the deepest section to be exposed. Basal peat exposed by subsequent erosion would be younger marginal peat, the age of which would not necessarily give a close limiting date for glacier recession. Because the original configuration and deepest sections of the sampled depressions could not be determined, this explanation may account for the apparently anomalous dates. If true, drift throughout a distance of 1.7 miles north of the mouth of the Salmon River which has been mapped as Chagvan Drift is probably more than 45,000 years old. (5) Peat composing samples UW-70, UW-71, and I-426 was deposited in a drainage channel of Unaluk age which was cut across Chagvan Drift, rather than in kettles of Chagvan age. If the Goodnews Bay glacier halted about 1.7 miles north of the present mouth of the Salmon River during the Unaluk Glaciation, meltwater flowing south across Chagvan Drift may have cut a channel which, following deglaciation, was abandoned and became the site of peat accumulation. Therefore, the age of basal peat would represent a minimum age for deglaciation following the maximum Unaluk advance. Although sediment-filled depressions exposed in the sea cliff are most reasonably interpreted as kettles, some may in fact be channel segments. Owing to coastal recession, the original shape and possible continuity of the depressions cannot be accurately reconstructed.

Assuming either (4) or (5) to be the most likely explanation, sediments near Flat Cape mapped as Chagvan Drift in Fig. 2 are more than 45,000 years old, while outermost Unaluk Drift is older than 8,900 years. These dates and the evidence from degree of weathering of the drift sheets indicate that the Unaluk Glaciation may be broadly correlative with the Naptowne Glaciation of the Cook Inlet Region, which Karlstrom (1964) has dated at between 39,000 and 5,500 years on the basis of samples collected from beneath Naptowne till and from sediments associated with final recession of Naptowne ice. The Unaluk Glaciation also appears to be the temporal equivalent of late ("classical") Wisconsin glaciation in central North America (Flint 1957, 1963) which encompassed an interval 
from more than 27,000 to less than 10,000 years ago. Although Chagvan Drift was deposited more than 45,000 years ago, the nonglacial interval separating the Chagvan and Unaluk glaciations may have been a major interstadial rather than a full interglaciation, as noted above. If true, the Chagvan Glaciation is most likely correlative with early Wisconsin advances of the Laurentide Ice Sheet which, according to Dreimanis et al. (1966), are more than 45,000 years old. It may also be correlative with the Knik Glaciation of Cook Inlet, which Karlstrom has dated as more than 48,000 years old, and which he correlates with early Wisconsin Glaciation (Péwé et al. 1965).

The sharp difference in weathering and morphology of the Chagvan and Clara Creek drifts, suggestive of a full interglacial interval between the times of their deposition, supports a pre-Wisconsin age for the Clara Creek. Morphology of Clara Creek Drift is grossly similar to that of Nome River Drift at Nome and elsewhere on Seward and Baldwin peninsulas (D. M. Hopkins, personal communication, 1967), which suggests possible correlation of these units. Stratigraphic evidence, reviewed by McCulloch et al. (1965), indicates that Nome River Drift is pre-Sangamon in age and correlates with drift of the Illinoian Glaciation of the central United States. Isotopic dating has shown that it is more than 100,000 and less than 175,000 years old (Péwé et al. 1965).

If a major interglaciation of long duration preceded the Clara Creek Glaciation, as inferred above, then the Kemuk Glaciation is very likely pre-Illinoian in age. Existing data bearing on the age of this drift do not permit more accurate interregional correlation at this time.

The four-fold glacial succession delineated at Chagvan Bay is comparable to several glacial sequences from nearby areas of subarctic Alaska in which two major Wisconsin and two pre-Wisconsin glaciations are recognized (Péwé et al. 1965). Although attempts at precise intraregional correlation based primarily on geomorphic criteria without supporting absolute dates can be hazardous, particularly where local differences in climate, lithology, and relief are involved, the close similarity in pattern among glacial sequences from subarctic Alaska suggests that the glacier fluctuations resulted from broadly synchronous changes of climate during the later part of the Pleistocene Epoch. Additional work on the Unaluk moraine sequence in the Ahklun Mountains and around Goodnews Bay should permit subdivision of the Unaluk Glaciation and possible correlation with stades of the Naptowne and "classical" Wisconsin glaciations.

\section{ACKNOWLEDGEMENTS}

I am indebted to the Fremont Mining Company for support during the course of geologic investigations at Chagvan Bay and for permission to publish part of the results of those studies. I am especially grateful to John P. McKee, Ed Berdusco, and other members of the exploration party of the Fremont Mining Company, and to personnel of the Goodnews Bay Mining Company for their close co-operation and kind hospitality during the project. John Brooks of the Fremont Mining Company ably assisted in the field work. The Goodnews Bay Mining Company kindly provided access to bore-hole records of the Salmon River valley that were of fundamental importance to the interpretation of the glacial history presented here. David M. Hopkins of the U.S. Geological Survey kindly made available to me comments from his unpublished field notes and data pertaining to a radiocarbon sample (I-426) collected by him at Flat Cape. Radiocarbon samples collected by me were 
dated at the Radiocarbon Laboratory of the University of Washington under the direction of Professor A. W. Fairhall. Critical review of a draft of the manuscript by A. L. Washburn and David M. Hopkins is deeply appreciated.

\section{REFERENCES}

Dreimanis, alexis, Jan terasmae, and G. D. mCkenzie, 1966. The Port Talbot Interstade of the Wisconsin Glaciation. Canadian Journal of Earth Sciences, 3: 305-25.

FLINT, R. F., 1957. Glacial and Pleistocene Geology. New York: John Wiley and Sons. 553 pp. 139: 402-4. 1963. Status of the Pleistocene Wisconsin Stage in central North America. Science,

Hamilton, G.L., 1921. Mineral resources of the Goodnews Bay region. U.S. Geological Survey Bulletin, 714-E: 207-28.

HOARE, J. M., 1961. Geology and tectonic setting of lower Kuskokwim-Bristol Bay region, Alaska. American Association of Petroleum Geologists Bulletin, 45: 594-611.

- and w. L. COONRAD, 1961a. Geologic map of the Goodnews Quadrangle, Alaska. U.S. Geological Survey Miscellaneous Geologic Investigations. Map 1-339.

$-1961 \mathrm{~b}$. Geologic map of the Hagemeister Island Quadrangle, Alaska. U.S. Geological Survey Miscellaneous Geologic. Investigations. Map I-321.

HOPKINS, D. M., 1959. Cenozoic history of the Bering Land Bridge. Science, 129: 1519-28.

KARLSTROM, T. N. v., 1964. Quaternary geology of the Kenai Lowland and glacial history of the Cook Inlet region, Alaska. U.S. Geological Survey Professional Paper 443. 69 pp.

MCCULLOCH, D. S., D. W. TAYLOR, and MEYER RUBIN, 1965. Stratigraphy, non-marine mollusks, and radiometric dates from Quaternary deposits in the Kotzebue Sound area, western Alaska. Journal of Geology, 73: 442-53.

MERTIE, J. B., JR., 1940. The Goodnews platinum deposits, Alaska. U.S. Geological Survey Bulletin $918.97 \mathrm{pp}$.

PÉWÉ, T. L., D. M. HOPKINS, and J. L. GIDDINGS, 1965. The Quaternary geology and archaeology of Alaska, in The Quaternary of the United States, H. E. Wright, Jr., and D. G. Frey, ed., pp. 355-74. Princeton: Princeton University Press.

POTZGER, J. E., 1956. Pollen profiles as indicators in the history of lake filling and bog formation. Ecology, 37: 476-83.

SPURR, J. E., 1900. A reconnaissance in southwestern Alaska in 1898. U.S. Geological Survey 20th Annual Report, Pt. 7, pp. 31-264. 